\title{
Curcumin: Therapeutical Potential in Ophthalmology
}

Authors

Affiliations
Nicola Pescosolido ${ }^{1}$, Rossella Giannotti ${ }^{2}$, Andrea Maria Plateroti ${ }^{2}$, Antonia Pascarella ${ }^{3}$, Marcella Nebbioso ${ }^{2}$

${ }^{1}$ Department of Cardiovascular, Respiratory, Nephrology, Geriatric, and Anesthetic Sciences, Sapienza University of Rome, Rome, Italy

${ }^{2}$ Department of Sense Organs, Sapienza University of Rome, Rome, Italy

${ }^{3}$ Department of Biology and Biotechnology “Charles Darwin”, Sapienza University of Rome, Rome, Italy
Key words

- anti-inflammatory drug

- antioxidant drug

- antitumor drug

- Curcuma longa

- Zingiberaceae

- Curcumin

- ocular diseases received March 30, 2013

revised October 7, 2013

accepted October 21, 2013

\section{Bibliography}

DOI http://dx.doi.org/ 10.1055/s-0033-1351074

Published online December 9 , 2013

Planta Med 2014; 80: 249-254

(C) Georg Thieme Verlag KG

Stuttgart · New York .

ISSN 0032-0943

\section{Correspondence}

Dr. Marcella Nebbioso

Department of Sense Organs

Centre of Ocular Electro-

physiology

Sapienza University of Rome

Viale del Policlinico 155

00161 Rome

Italy

Phone: + 390649975422

Fax: + 390649975425

marcella.nebbioso@uniroma1.it

\section{Abstract}

$\nabla$

Curcumin (diferuloylmethane) is the main curcuminoid of the popular Indian spice turmeric (Curcuma longa). In the last 50 years, in vitro and in vivo experiments supported the main role of polyphenols and curcumin for the prevention and treatment of many different inflammatory diseases and tumors.

The anti-inflammatory, antioxidant, and antitumor properties of curcumin are due to different cellular mechanisms: this compound, in fact, produces different responses in different cell types. Unfortunately, because of its low solubility and oral bioavailability, the biomedical potential of

\section{Introduction}

$\nabla$

Curcumin (diferuloylmethane) is the orange and water-insoluble pigment extracted from turmeric, the rhizome of Curcuma longa, a species that belongs to the Zingiberaceae family. The powder obtained from the turmeric root, the main ingredient of curry, contains $2-5 \%$ of curcumin. Due to its chemical and biological properties, curcumin is one of the so-called phytochemical compounds, biologically active molecules produced by plants with beneficial effects on health, that also include $\beta$-carotene, lycopene, epigallocatechinegallate, and quercetin [1-3]. The therapeutic use of the plant dates back to Indian Ayurvedic medicine, and curcumin is still nowadays commonly used as a spice and as a colorant in Indian cooking and in the whole South-East Asia.

In the last few years, several curcumin analogues have been tested, but in most cases they were found to be less effective than curcumin itself. On the contrary, dimethoxycurcumin showed good results probably because of the absence of free phenolic groups that prevent its conversion to glucuronide and to sulfate, resulting in better bio- curcumin is not easy to exploit; for this reason more attention has been given to nanoparticles and liposomes, which are able to improve curcumin's bioavailability. Pharmacologically, curcumin does not show any dose-limiting toxicity when it is administered at doses of up to $8 \mathrm{~g} /$ day for three months. It has been demonstrated that curcumin has beneficial effects on several ocular diseases, such as chronic anterior uveitis, diabetic retinopathy, glaucoma, age-related macular degeneration, and dry eye syndrome. The purpose of this review is to report what has so far been elucidated about curcumin properties and its potential use in ophthalmology.

availability [4]. In the last years, several studies have confirmed the potential use of curcumin for the prevention and treatment of many different diseases, especially inflammatory ones and cancer [1-8]. In particular, several studies confirmed a chemopreventive role for curcumin in tumors from different cell types (pancreas, breast, prostate, lung, mantle cell lymphoma, liver, brain, colorectal cancer, and others) $[2,7,8]$. Several studies focused the effect of curcumin and its analogs on the nuclear factor $k \mathrm{~B}(\mathrm{NF}-k \mathrm{~B})$, and demonstrated that curcumin is able to downregulate the expression of genes involved in apoptosis, proliferation, and transformation, by inhibiting the NF- $k$ B activation [7].

The anti-inflammatory properties of curcumin were linked to its ability to downregulate the expression of the I $k \mathrm{~B} \alpha$ gene, cyclooxygenase- 2 gene (COX-2), prostaglandin E-2 (PGE-2), interleukin1-6-8 (IL-1, IL-6, IL-8), and tumor necrosis factor- $\alpha$ (TNF- $\alpha$ ) ( Fig. 1). In addition, curcumin inhibits the free radicals production, and so exhibits antioxidant properties [5].

Other studies demonstrated that curcumin may exert an anti-inflammatory effect through the ac- 


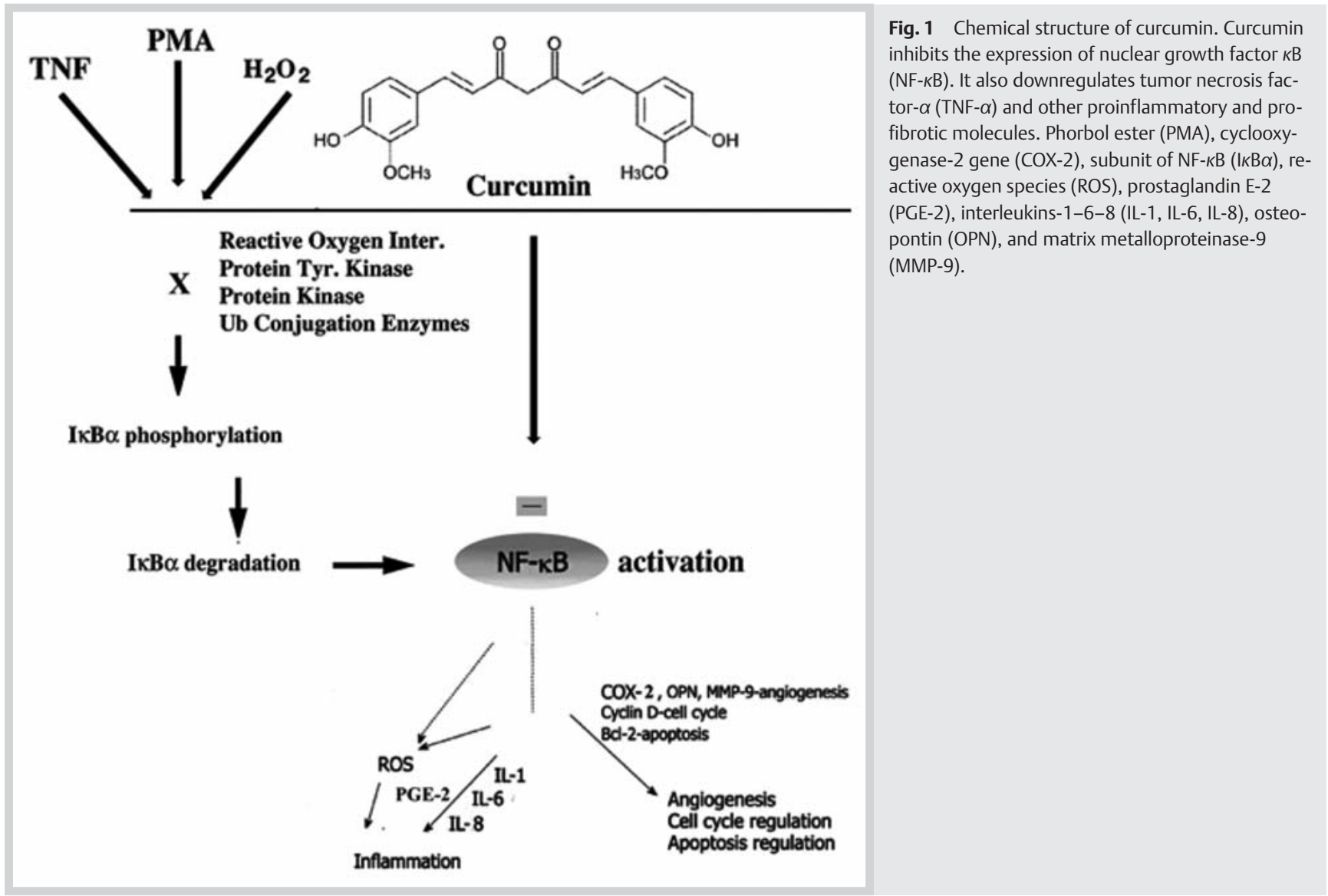

tivation of peroxisome proliferator-activated receptor- $\gamma$ (PPAR- $\gamma$ ) [9]. PPAR- $\gamma$ is the most studied factor of the nuclear receptor proteins PPARs, a group of transcriptional factors that regulate gene expression [9]. PPAR- $\gamma$ in fact binds to the peroxisome proliferator response element (PPRE) in the promoter sequence of genes and therefore regulates gene transcription.

Unfortunately, because of its low solubility and oral bioavailability, the biomedical potential of curcumin is not easy to exploit, although in 1998 Shoba et al. found that piperine, an alkaloid responsible for the pungency of black pepper, administered along with curcumin significantly improved the plasma concentrations of curcumin both in animals and humans [10]. However, the administration of significant amounts of piperine (doses above $15 \mathrm{mg} /$ day) is not recommended because it has shown to possess a bioavailability enhancing activity with selected drugs [10].

Only recently, studies demonstrated that additional benefits may accrue with the synergism of essential oils and curcuminoids [11]. Synergism between curcumin and other natural components of turmeric (i.e., turmeric essential oil) has been exploited in a proprietary patented formulation trade-named BCM-95 ${ }^{\circledR}$ (Bio-Curcumin). In healthy human volunteers, the blood levels of curcumin after ingestion of BCM-95 ${ }^{\circledR}$ increased 6.93-fold compared to plain curcumin and 6.3-fold compared to a curcuminlecithin-piperine formulation [12]. Moreover, curcumin retention time in the bloodstream lasted only four to five hours, while BCM- $95^{\circledR}$ was retained for about eight hours, with a higher level of curcumin in the blood at all time points. This superior absorption and retention is attained by a patented process involving homogenization and micronization with turmeric essential oil that later will be bound to natural plant phospholipids $[11,12]$.
In an attempt to enhance curcumin bioavailability, delivery systems including liposomal curcumin, encapsulated and nanoparticle-encapsulated curcumin formulations, are also being explored [13-16]. However, the techno-economic feasibility of these compounds is currently unknown $[17,18]$.

Due to the complexity of the eye anatomical structures and the specificity required for the treatment of each disease, it would be useful to summarize the knowledge about curcumin effects and remark on its potential use in ophthalmology.

\section{Use in Ophthalmology \\ $\nabla$}

Molecular mechanisms

In vitro data: Different in vitro experiments showed the possible role of curcumin in the treatment of common ophthalmological conditions, such as dry eye syndrome and proliferative vitreoretinopathy (PVR) [19-21].

Dry eye syndrome is characterized by a quantitative and qualitative alteration of the tears at the ocular surface. It has been reported that an increased osmolarity of the culture medium produces increased levels of IL- $1 \beta$, IL- 6 , and TNF- $\alpha$ and activates p38 MAP kinase, JNK MAP kinase, and NF- $k$ B in corneal epithelial cells [19]. In that experiment, a culture media osmolarity of up to 450 mOsm was obtained by adding a solution of $\mathrm{NaCl}$, and cytokine production was assessed after $24 \mathrm{~h}$. Pretreatment with $5 \mathrm{mmol}$ of curcumin added to the medium inhibited IL- $1 \beta$ production, p38 and NF- $k$ B activation, and decreased JNK activation, suggesting a possible role for curcumin in the treatment of dry eye syndrome [19]. 
PVR involves the posterior segment of the eye and probably follows primary retinal detachment. When the retinal cell layers come in contact with vitreous cytokines, retinal pigmented epithelium (RPE) cells proliferate, migrate and undergo an epithelial-mesenchymal transition (EMT): fibrotic membranes grow up and pull the retina inwards, leading to secondary retinal detachment [20]. In cultured human RPE cells, curcumin was able to inhibit cell proliferation by triggering caspase 3/7-dependent (but caspase 8-independent) cell death and necrosis, therefore showing a possible therapeutic role in PVR [20].

In vivo experimental data: The anti-inflammatory effects of curcumin on the eye were also confirmed with in vivo experiments. Mrudula et al. [21] and Gupta et al. [22] showed the potential effects of treatment with curcumin in mice with diabetic retinopathy induced by the administration of streptozocin. Results were observed with a transmission electron microscope, PCR, and immunoblotting. The first study demonstrated that an 8-week diet enriched with $0.01 \%$ curcumin or $0.5 \%$ Curcuma longa reduced VEGF expression in treated mice when compared to controls [21]. In the second study, a 16-week treatment with $1 \mathrm{~g}$ of curcumin per $\mathrm{kg}$ of body weight reduced retinal glutathione, superoxide dismutase, catalase, TNF- $\alpha$, and VEGF levels and mitigated diabetic typical endothelial features [21].

Kowluru and Kanwar [23] found, in addition, that curcumin is able either to protect cellular antioxidant properties or to downregulate IL- $1 \beta$, VEGF, and NF- $\kappa$ B levels without influencing glucose blood levels in diabetic mice.

In these animals, venular leukocyte adhesion is apparent in the microcirculation of the iridal tissue through video microscopy. Other researchers demonstrated both in mice treated with curcumin at a daily oral dosage of $300 \mathrm{mg} / \mathrm{kg}$ of body weight and those treated with curcumin + vitamin C ( $1 \mathrm{~g} / \mathrm{L}$ ascorbic acid) that leukocyte adhesion, blood glucose levels, dyslipidemia, and HbA1c were reduced, thus confirming the protective role for curcumin and vitamin C on endothelial cells [24].

In a mice model of cataract (induced by administration of $15 \mu \mathrm{mol} / \mathrm{kg}$ of body weight of sodium selenite), the pretreatment with $75 \mathrm{mg} / \mathrm{kg}$ of body weight of curcumin produced lower free radical levels in the lenses, prevented the $\mathrm{Ca}(2+)$ ATPase inactivation and therefore the accumulation of $\mathrm{Ca}(2+)$ that causes, in turn, the activation of calpain-mediated proteolysis and lens clouding [25].

Similar results were obtained in mice with galactose-induced cataract. Slit lamp microscope examination showed that a diet enriched with $0.002 \%$ curcumin delays the onset and progression of cataract [26]. Indeed, curcumin could exert, at very low concentrations, antioxidant and antiglycating effects, through inhibition of lipid peroxidation, advanced glycated end products, and protein aggregation. On the other hand, higher levels of curcumin $(0.01 \%)$ in the diet may induce opposite effects [27].

Arbiser et al. demonstrated that a diet enriched with $80 \mathrm{ng}$ of basic fibroblast growth factor (bFGF) $+44 \mu$ g curcumin (or curcumin analogue), administered after intrastromal linear keratotomy, was able to inhibit bFGF-induced neovascularization in mice [28].

\section{Curcumin and PPAR-y}

Nuclear PPAR- $\gamma$ (that is found both in neuronal and RPE cells) activation was found to be involved in the ocular damage onset and plays a modulatory role in inflammation $[29,30]$.

In diabetic patients, PPAR- $\gamma$ agonists are able to decrease the level of several markers of inflammation, such as plasma C-reactive protein (CRP), IL-6, monocyte chemotactic protein (MCP-1), plas- minogen activator inhibitor-1 (PAI-1), soluble CD40 ligand [sCD40L], and the matrix metalloproteinase-9 (MMP-9) [31-36]. These effects are linked to NF- $k$ B downregulation and to a reduced production of reactive oxygen species (ROS) [36-40]. PPAR- $\gamma$ agonists (troglitazone, ciglitazone, pioglitazone) were studied in animal models of diabetic retinopathy and demonstrated their ability to improve retinal microcirculation in the early stages of disease by stimulating nitric oxide (NO) production whose reduction in the first stages of retinopathy may contribute to the hemodynamic damage [40]. On the other hand, NO formed by inducible NOS (iNOS) expressed under influences of inflammatory mediators evokes neurodegeneration and cell apoptosis, leading to serious ocular diseases. NO overproduced by neuronal NOS (nNOS) in the retina stimulated by excitotoxic amino acids or exposed to ischemia also mediates retinal injury. Because of these dichotomous roles of NO, which has both beneficial and pathogenic actions, one may face difficulties in constructing therapeutic strategies with NO supplementation or NOS inhibition [40].

In vitro and in vivo models studies also demonstrated antiangiogenic properties of the PPAR- $\gamma$ ligands [41-47].

In particular, they appeared to play an antiangiogenic role in agerelated macular degeneration (AMD), inhibiting the migration of MAP kinase-dependent smooth muscle cells and acting as a VEGF inhibitor [41]. Other studies showed that PPAR- $\gamma$ ligands are able to inhibit cell proliferation induced by growth factors, to downregulate the tissue plasminogen activator and to suppress endothelin-1 secretion [46-49]. Drüsen in AMD are presently believed to result from the infiltration of microglial cells into the RPE layer and their transformation into foam cells [50]. Microglial cells are the main macrophage population of the brain, and their activity is controlled by PPAR- $\gamma$. Although their role has been largely underestimated for a long time, microglial cells are able both to protect and damage the retinal tissue: in physiological conditions they are quiescent, and the retina is isolated from immunological response-related damage; once activated, they secrete cytokines (TNF- $\alpha$, INF- $\gamma$ ) and upregulate the expression of vascular cell adhesion molecules promoting leukocytes and macrophages recruitment [50]. These pathogenetic events were demonstrated not only for AMD, but also for other ocular conditions, such as glaucomatous optic nerve degeneration, retinitis pigmentosa, and ischemia-reperfusion damage [51-54]. Curcumin, a PPAR- $\gamma$ agonist, may therefore play a role in mitigating the progression of AMD through a downregulation of the proinflammatory functions of microglia [52-55]. The anti-inflammatory and antioxidant effects induced by curcumin activation of PPAR- $\gamma$ are associated, as mentioned, with the NF- $k$ B pathway. PPAR- $\gamma$-mediated suppression of NF- $k$ B may reduce the amount of proinflammatory cytokines in macrophages, such as MMP-9, that seems to play an important role in ocular diseases [56-58]. Curcumin activates PPAR- $\gamma$ that, in turn, downregulates MMPs production: it is well known that MMP-9 causes extracellular matrix degradation and stimulates RPE cell migration to the Bruch's membrane, thus contributing to AMD pathogenesis [52,53].

In a murine model of laser-induced choroidal neovascolarization (CNV), uveal endothelial cells and RPE cells expressed PPAR- $\gamma$. The response to VEGF, produced by resident macrophages after hypoxia, was inhibited by agonists of PPAR- $\gamma$ itself. Intraperitoneal administration of curcumin ( $20 \mathrm{mg} / \mathrm{kg} /$ day $)$ significantly reduced the occurrence of damage $(p<0.001)$, compared with the control group [53]. 
Even in cases of optic neuritis (ON), an inflammatory demyelinating disease that usually represents the first symptom of multiple sclerosis (MS), agonists of PPAR- $\gamma$ (15 d-PGJ 2 and gemfibrozil) may reduce the macrophagic infiltration in the lesions, as demonstrated in mice with autoimmune encephalitis (animal models of MS) [54]. Although additional confirmations are needed, it is clear that curcumin can reduce the progression of ON through increased PPAR- $\gamma$ levels. Curcumin, indeed, binds both PPAR- $\gamma$ receptors and retinoic acid receptors; this heterodimer, in turn, binds the PPRE of several genes, as demonstrated for the TNF- $\alpha$ gene in hepatic sepsis [55].

\section{Clinical data and bioavailability of curcumin}

The anti-inflammatory effects of curcumin on the anterior segment were investigated in instances of chronic anterior uveitis and inflammatory orbital pseudotumor. Thirty-two patients with chronic anterior uveitis were divided into two subgroups. $375 \mathrm{mg}$ of curcumin were administered orally 3 times a day for 12 weeks to the participants in the first group $(\mathrm{n}=18)$. Patients in group 2 $(\mathrm{n}=14)$ received, in addition, an antituberculosis prescription, due to their positivity to the Mantoux test. The ocular conditions of all patients from the first group significantly improved (86\%) when compared to subjects from group 2. Since curcumin has no side effects, it could be a promising substitute for corticosteroid treatment [56].

These results were confirmed in a study of 122 patients with chronic uveitis from different etiologies, who were treated orally for 18 months with $600 \mathrm{mg}$ twice a day of a more bioavailable complex of curcumin-phosphatidylcholine, Meriva ${ }^{\circledR}$ (Indena), formulated as Norflo ${ }^{\circledR}$ tablets (Eye Pharma Co.). At the end of a 12 month follow-up period, the number of relapses of the disease was 36 against the 275 occurring before treatment in the same group of patients [57].

Also 5 patients with idiopathic inflammatory orbital pseudotumor, treated orally with curcumin ( $375 \mathrm{mg} 3$ times a day) for 622 months, showed regression of the inflammatory signs at subsequent follow-ups performed every 3 months [58]. Five patients completed the study, out of which four recovered completely, while in one patient the swelling regressed completely but some limitation of movement persisted [58].

The main complication to the clinical diffusion of curcumin remains the low gastrointestinal absorption and the fast hepatic and intestinal metabolism $[3,59]$. Several formulations have been studied to overcome this limitation and increase the bioavailability of curcumin. One formulation proposes to place curcumin in a phytosome made of phospholipids in order to protect it from intestinal hydrolysis. The formulation of the complex lecithin phospholipids-curcumin (Meriva ${ }^{\circledR}$ ) increases over 20 times the bioavailability compared with plain curcumin, so allowing a better use of curcumin and validating all those studies in which it was expected that high doses of curcumin were difficult to achieve due to a poor compliance of patients.

Meriva ${ }^{\circledR}$ underwent pharmacokinetic tests both in animals and humans and showed significantly increased areas under the curve (AUC) and $C_{\max }$ (bioavailability of curcumin) $[60,61]$. The administration of $1 \mathrm{~g}$ of Meriva corresponds to more than 5 grams of curcumin alone. After these results, turmeric phospholipid was used for the formulation of $\mathrm{Norflo}^{\circledR}$, a food supplement which, as for curcumin, may act in a natural way in ophthalmic diseases by modulating the physiological and inflammatory processes [57,62].
In the future, nanoparticles may prove able to solubilize curcumin, as demonstrated on human tumor pancreatic cell experiments, though this still needs to be tested in vivo $[63,64]$.

After encapsulation of curcumin in a liposomal delivery system that allows for its i.v. administration, the effects on proliferation, apoptosis, signal transduction, and angiogenesis were evaluated both in vitro and in vivo. Results were in agreement with previous data, showing an irreversible growth inhibition, apoptosis, and downregulation of NF- $k$ B, VEGF, IL-8, and endothelial cell marker CD-31. The activity of liposomal curcumin was equal to or greater than that of curcumin at equimolar concentrations. In vivo, curcumin suppressed pancreatic carcinoma growth in murine xenograft models and inhibited tumor angiogenesis. Liposomal curcumin downregulated the NF- $k$ B machinery, suppressed growth and induced apoptosis of human pancreatic cells in vitro [64].

Eye diseases can ameliorate in response to oral curcumin administration. Unfortunately, there are no clinical studies showing the effectiveness and safety of curcumin eyedrops.

\section{Conclusions}

$\nabla$

Experimental and clinical data obtained so far indicate that oral supplementation with curcumin is well tolerated and has been shown to be safe in humans. It could reduce symptoms and signs of eye discomfort after a few weeks of treatment. Most studies demonstrated its potential therapeutic role and its efficacy in eye relapsing diseases, such as dry eye syndrome, allergic conjunctivitis, anterior uveitis, glaucoma, maculopathy, and ischemic and diabetic retinopathy. Curcumin treatment results in a partial, but significant, inhibition of neuronal and vascular damage during ischemic or oxidative stress, angiogenesis, cellular malignant transformation, metastasis, and inflammatory diseases. In light of its angiogenesis-modulating profile and anti-inflammatory properties, curcumin has great potential in the treatment of inflammatory and neovascular proliferative diseases of the retina. The mechanism by which curcumin induces its effects is yet to be fully elucidated, but many studies have shown its relevance as a potent anti-inflammatory and immunomodulating agent. Indeed, curcumin with its pleiotropic activities can modulate the expression and activation of many cellular regulatory proteins such as chemokines, interleukins, hematopoietic growth factors, and transcription factors, which in turn inhibit cellular inflammatory responses and protect cells [5-7]. We hypothesize that curcumin could be an effective nutraceutical compound for preventive and augmentative therapy of several ocular diseases. In conclusion, in view of curcumin's pleiotropic effects on cell death and survival, it could also be interesting to further investigate topical administration of curcumin for eye diseases.

\section{Conflict of Interest}

$\nabla$

The authors declare no conflict of interest.

\section{References}

1 Shishodia S. Molecular mechanisms of curcumin action: gene expression. Biofactors 2013; 39: 37-55

2 Talero E, Ávila-Roman J, Motilva V. Chemoprevention with phytonutrients and microalgae products in chronic inflammation and colon cancer. Curr Pharm Des 2012; 18: 3939-3965 
3 Ammon HP, Wahl MA. Pharmacology of Curcuma longa. Planta Med 1991; 57: 1-7

4 Tamvakopoulos C, Dimas K, Sofianos ZD, Hatziantoniou S, Han Z, Liu ZL, Wyche JH, Pantazis P. Metabolism and anticancer activity of curcumin analogue, dimethoxycurcumin. Clin Cancer Res 2007; 13: 1269-1277

5 Taylor RA, Leonard MC. Curcumin for inflammatory bowel disease: a review of human studies. Altern Med Rev 2011; 16: 152-156

6 Carmona-Ramírez I, Santamaría A, Tobón-Velasco JC, Orozco-Ibarra M, González-Herrera IG, Pedraza-Chaverrí J, Maldonado PD. Curcumin restores Nrf2 levels and prevents quinolinic acid-induced neurotoxicity. J Nutr Biochem 2013; 24: 14-24

7 Aggarwal S, Ichikawa H, Takada Y, Sandur SK, Shishodia S, Aggarwal BB. Curcumin (diferuloylmethane) down-regulates expression of cell proliferation and antiapoptotic and metastatic gene products through suppression of I $k \mathrm{~B} \alpha$ Kinase and akt activation. Mol Pharmacol 2006; 69: 195-206

8 Prud'homme GJ. Cancer stem cells and novel targets for antitumor strategies. Curr Pharm Des 2012; 18: 2838-2849

9 Michalik L, Auwerx J, Berger JP, Chatterjee VK, Glass CK, Gonzalez FJ, Grimaldi PA, Kadowaki T, Lazar MA, O'Rahilly S, Palmer CN, Plutzky J, Reddy $J K$, Spiegelman BM, Staels B, Wahli W. International Union of Pharmacology. LXI. Peroxisome proliferator-activated receptors. Pharmacol Rev 2006; 58: 726-741

10 Shoba G, Joy D, Joseph T, Majeed M, Rajendran R, Srinivas PS. Influence of piperine on the pharmacokinetics of curcumin in animals and human volunteers. Planta Med 1998; 64: 353-356

11 Yue GGL, Cheng SW, Yu H, Xu ZS, Lee JK, Hon PM, Lee MY, Kennelly EJ, Deng G, Yeung SK, Cassileth BR, Fung KP, Leung PC, Lau CB. The role of turmerones on curcumin transportation and P-glycoprotein activities in intestinal Caco-2 cells. J Med Food 2012; 15: 242-252

12 Antony B, Merina B, Iyer VS, Judy N, Lennertz K, Joyal S. A pilot cross-over study to evaluate human oral bioavailability of BCM-95 ${ }^{\circledR} \mathrm{CG}$ (Biocurcu$\max ^{\mathrm{TM}}$ ), a novel bioenhanced preparation of curcumin. Indian J Pharm Sci 2008; 70: 445-449

13 Rachmawati H, Shaal LA, Müller RH, Keck CM. Development of curcumin nanocrystal: physical aspects. J Pharm Sci 2013; 102: 204-214

14 Li L, Ahmed B, Mehta K, Kurzrock R. Liposomal curcumin with and without oxaliplatin: effects on cell growth, apoptosis, and angiogenesis in colorectal cancer. Mol Cancer Ther 2007; 6: 1276-1282

15 Kumar V, Lewis SA, Mutalik S, Shenoy DB, Venkatesh, Udupa N. Biodegradable microspheres of curcumin for treatment of inflammation. Indian J Physiol Pharmacol 2002; 46: 209-217

16 Bisht S, Feldmann G, Soni S, Ravi R, Karikar C, Maitra A, Maitra A. Polymeric nanoparticle-encapsulated curcumin (nanocurcumin): a novel strategy for human cancer therapy. J Nanobiotechnol 2007; 5: 3

17 Gong C, Deng S, Wu Q Xiang M, Wei X, Li L, Gao X, Wang B, Sun L, Chen Y, Li Y, Liu L, Qian Z, Wei Y. Improving antiangiogenesis and anti-tumor activity of curcumin by biodegradable polymeric micelles. Biomaterials 2013; 34: 1413-1432

18 Steigerwalt R, Nebbioso M, Appendino G, Belcaro G, Ciammaichella G, Cornelli U, Luzzi R, Togni S, Dugall M, Cesarone MR, Ippolito E, Errichi $B M$, Ledda A, Hosoi M, Corsi M. Meriva ${ }^{\circledR}$, a lecithinized curcumin delivery system, in diabetic microangiopathy and retinopathy. Panminerva Med 2012; 54: 11-16

19 Chen M, Hu DN, Pan Z, Lu CW, Xue CY, Aass I. Curcumin protects against hyperosmoticity-induced IL-1beta elevation in human corneal epithelial cell via MAPK pathways. Exp Eye Res 2010; 90: 437-443

20 Alex AF, Spitznas M, Tittel AP, Kurts C, Eter N. Inhibitory effect of epigallocatechingallate (EGCG), resveratrol, and curcumin on proliferation of human retinal pigment epithelial cells in vitro. Curr Eye Res 2010; 35: 1021-1033

21 Mrudula T, Suryanarayana P, Srinivas PN, Reddy GB. Effect of curcumin on hyperglycemia-induced vascular endothelial growth factor expression in streptozotocin-induced diabetic rat retina. Biochem Biophys Res Commun 2007; 361: 528-532

22 Gupta SK, Kumar B, Nag TC, Agrawal SS, Agrawal R, Agrawal P, Saxena R, Srivastava S. Curcumin prevents experimental diabetic retinopathy in rats through its hypoglycemic, antioxidant, and anti-inflammatory mechanisms. J Ocul Pharmacol Ther 2011; 27: 123-130

23 Kowluru RA, Kanwar M. Effects of curcumin on retinal oxidative stress and inflammation in diabetes. Nutr Metab (Lond) 2007; 16: 4-8

24 Patumraj S, Wongeakin N, Sridulyakul P, Jariyapongskul A, Futrakul N, Bunnag S. Combined effects of curcumin and vitamin $C$ to protect endothelial dysfunction in the iris tissue of STZ-induced diabetic rats. Clin Hemorheol Microcirc 2006; 35: 481-489
25 Manikandan R, Thiagarajan R, Beulaja S, Sudhandiran G, Arumugam M. Curcumin prevents free radical-mediated cataractogenesis through modulations in lens calcium. Free Radic Biol Med 2010; 48: 483-492

26 Suryanarayana P, Krishnaswamy K, Reddy GB. Effect of curcumin on galactose-induced cataractogenesis in rats. Mol Vis 2003; 9: 223-230

27 Libby P, Plutzky J. Inflammation in diabetes mellitus: role of peroxisome proliferator-activated receptor- $\alpha$ and peroxisome proliferatoractivated receptor- $\gamma$ agonists. Am J Cardiol 2007; 99: 27B-40B

28 Arbiser JL, Klauber N, Rohan R, van Leeuwen R, Huang MT, Fisher C, Flynn $E$, Byers HR. Curcumin is an in vivo inhibitor of angiogenesis. Mol Med 1998; 4: 376-383

29 Malchiodi-Albedi F, Matteucci A, Bernardo A. PPAR gamma, microglial cells, and ocular inflammation: new venues for potential therapeutic approaches. PPAR Res 2008; 2008: 295784

30 Aljada A, Garg R, Ghanim H, Mohanty P, Hamouda W, Assian E, Dandona $P$. Nuclear factor- $k B$ suppressive and inhibitor- $k B$ stimulatory effects of troglitazone in obese patients with type 2 diabetes: evidence of an antiinflammatory action? J Clin Endocrinol Metab 2001; 86: 32503256

31 Haffner SM, Greenberg AS, Weston WM, Chen H, Williams K, Freed MI. Effect of rosiglitazone treatment on nontraditional markers of cardiovascular disease in patients with type 2 diabetes mellitus. Circulation 2002; 106: 679-684

32 Marx N, Imhof A, Froehlich J, Siam L, Ittner J, Wierse G, Schmidt A, Maerz $W$, Hombach $V$, Koenig $W$. Effect of rosiglitazone treatment on soluble CD40 $\mathrm{L}$ in patients with type 2 diabetes and coronary artery disease. Circulation 2003; 107: 1954-1957

33 Mohanty P, Aljada A, Ghanim H, Hofmeyer D, Tripathy D, Syed T, Al-Haddad W, Dhindsa S, Dandona P. Evidence for a potent antiinflammatory effect of rosiglitazone. J Clin Endocrinol Metab 2004; 89: 2728-2735

34 Wang G, Wei J, Guan Y, Jin N, Mao J, Wang X. Peroxisome proliferatoractivated receptor- $\gamma$ agonist rosiglitazone reduces clinical inflammatory responses in type 2 diabetes with coronary artery disease after coronary angioplasty. Metabolism 2005; 54: 590-597

35 Agarwal R. Anti-inflammatory effects of short-term pioglitazone therapy in men with advanced diabetic nephropathy. Am J Renal Physiol 2006; 290: F600-F605

36 Aljada A, Garg R, Ghanim H, Mohanty P, Hamouda W, Assian E, Dandona $P$. Nuclear factor- $k B$ suppressive and inhibitor- $k B$ stimulatory effects of troglitazone in obese patients with type 2 diabetes: evidence of an antiinflammatory action? J Clin Endocrinol Metab 2001; 86: 32503256

37 Haffner SM, Greenberg AS, Weston WM, Chen H, Williams K, Freed MI. Effect of rosiglitazone treatment on nontraditional markers of cardiovascular disease in patients with type 2 diabetes mellitus. Circulation 2002; 106: 679-684

38 Marx N, Imhof A, Froehlich J, Siam L, Ittner J, Wierse G, Schmidt A, Maerz $W$, Hombach $V$, Koenig $W$. Effect of rosiglitazone treatment on soluble CD40 L in patients with type 2 diabetes and coronary artery disease. Circulation 2003; 107: 1954-1957

39 Mohanty P, Aljada A, Ghanim H, Hofmeyer D, Tripathy D, Syed T, Al-Haddad W, Dhindsa S, Dandona P. Evidence for a potent antiinflammatory effect of rosiglitazone. J Clin Endocrinol Metab 2004; 89: 2728-2735

40 Toda N, Nakanishi-Toda M. Nitric oxide: ocular blood flow, glaucoma, and diabetic retinopathy. Prog Retin Eye Res 2007; 26: 205-238

41 Murata T, He S, Hangai M, Ishibashi T, Xi XP, Kim S, Hsueh WA, Ryan SJ, Law RE, Hinton DR. Peroxisome proliferator-activated receptor- $\gamma$ ligands inhibit choroidal neovascularization. Invest Ophthalmol Vis Sci 2000; 41: 2309-2317

42 Bonne C. PPAR gamma: a novel pharmacological target against retinal and choroidal neovascularization. J Fr Ophtalmol 2005; 28: 326-330

43 Sato $M$. Peroxisome proliferator activated receptor ligands and angiogenesis. Nihon Rinsho 2005; 63: 603-608

44 Sarayba MA, Li L, Tungsiripat T. Inhibition of corneal neovascularization by a peroxisome proliferator-activated receptor-gamma ligand. Exp Eye Res 2005; 80: 435-442

45 Del V Cano M, Gehlbach PL. PPAR-alpha Ligands as potential therapeutic agents for wet age-related macular degeneration. PPAR Res 2008; 2008: 821592

46 Gralinski MR, Rowse PE, Breider MA. Effects of troglitazone and pioglitazone on cytokine-mediated endothelial cell proliferation in vitro. J Cardiovasc Pharmacol 1998; 31: 909-913

47 Lee KJ, Kim HA, Kim PH, Lee HS, Ma KR, Park JH, Kim DJ, Hahn JH. Ox-LDL suppresses PMA-induced MMP-9 expression and activity through CD36-mediated activation of PPAR- $\gamma$. Exp Mol Med 2004; 36: 534-544 
48 Delerive P, Martin-Nizard F, Chinetti G, Trottein F, Fruchart JC, Najib J, Duriez P, Staels B. Peroxisome proliferator-activated receptor activators inhibit thrombininduced endothelin-1 production in human vascular endothelial cells by inhibiting the activator protein-1 signaling pathway. Circ Res 1999; 85: 394-402

49 Salvatore S, Vingolo EM. Endothelin-1 role in human eye: a review. J Ophthalmol 2010; 2010: 354645

50 Combadière C, Feumi C, Raoul W, Keller N, Rodéro M, Pézard A, Lavalette S, Houssier M, Jonet L, Picard E, Debré P, Sirinyan M, Deterre P, Ferroukhi $T$, Cohen SY, Chauvaud D, Jeanny JC, Chemtob S, Behar-Cohen F, Sennlaub F. CX3CR1-dependent subretinal microglia cell accumulation is associated with cardinal features of age-related macular de generation. J Clin Invest 2007; 117: 2920-2928

51 Gregory MS, Hackett CG, Abernathy EF, Lee KS, Saff RR, Hohlbaum AM, Moody KS, Hobson MW, Jones A, Kolovou P, Karray S, Giani A, John SW, Chen DF, Marshak-Rothstein A, Ksander BR. Opposing roles for membrane bound and soluble Fas ligand in glaucoma-associated retinal ganglion cell death. PLoS ONE 2011; 6: e17659

52 Herzlich AA, Tuo J, Chan CC. Peroxisome proliferator-activated receptor and age-related macular degeneration. PPAR Res 2008; 2008: 389507

53 Passos E, Grinstead RL, Khoobehi B. Effectiveness of curcumin, an angiogenesis inhibitor, in experimental choroidal neovascularization in rats. Invest Ophthalmol Vis Sci 2002; 43: E-Abstract 1274

54 Diab A, Hussain RZ, Lovett-Racke AE, Chavis JA, Drew PD, Racke MK. Ligands for the peroxisome proliferator-activated receptor- $\gamma$ and the retinoid $\mathrm{X}$ receptor exert additive anti-inflammatory effects on experimental autoimmune encephalomyelitis. J Neuroimmunol 2004; 148: 116-126

55 Jacob A, Wu R, Zhou M, Wang P. Mechanism of the anti-inflammatory effect of curcumin: PPAR- $\gamma$ activation. PPAR Res 2007; 2007: 89369
56 Lal B, Kapoor AK, Asthana OP, Agrawal PK, Prasad R, Kumar P, Srimal RC. Efficacy of curcumin in the management of chronic anterior uveitis. Phytother Res 1999; 13: 318-322

57 Allegri P, Mastromarino A, Neri P. Management of chronic anterior uveitis relapses: efficacy of oral phospholipidic curcumin treatment. Longterm follow-up. Clin Ophthalmol 2010; 4: 1201-1206

58 Lal B, Kapoor AK, Agrawal PK, Asthana OP, Srimal RC. Role of curcumin in idiopathic inflammatory orbital pseudotumours. Phytother Res 2000; 14: 443-447

59 Graber-Maier A, Büter KB, Aeschlimann J, Bittel C, Kreuter M, Drewe J, Gutmann H. Effects of Curcuma extracts and curcuminoids on expression of P-glycoprotein and cytochrome P450 3A4 in the intestinal cell culture model LS180. Planta Med 2010; 76: 1866-1870

60 Marczylo TH, Verschoyle RD, Cooke DN, Morazzoni P, Steward WP, Gescher AJ. Comparison of systemic availability of curcumin with that of curcumin formulated with phosphatidylcholine. Cancer Chemother Pharmacol 2007; 60: 171-177

61 Maiti K, Mukherjee K, Gantait A, Saha BP, Mukherjee PK. Curcuminphospholipid complex: Preparation, therapeutic evaluation and pharmacokinetic study in rats. Int J Pharm 2007; 330: 155-163

62 Mazzolani F, Togni S. Oral administration of a curcumin-phospholipid delivery system for the treatment of central serous chorioretinopathy: a 12-month follow-up study. Clin Ophthalmol 2013; 7: 939-945

63 Bisht S, Feldmann G, Soni S, Ravi R, Karikar C, Maitra A, Maitra A. Polymeric nanoparticle-encapsulated curcumin ("nanocurcumin"): a novel strategy for human cancer therapy. J Nanobiotechnol 2007; 5: 3

64 Li L, Braiteh SF, Kurzrock R. Liposome-encapsulated curcumin. in vitro and in vivo effects on proliferation, apoptosis, signaling, and angiogenesis. Cancer 2005; 104: 1322-1331 